\title{
THE ROLE OF INTERNATIONAL LEGAL ACTS IN THE IMPLEMENTATION OF PROPERTY RIGHTS
}

\author{
FARAJOVA Qandab Imran - dissertator of the Institute of Law and Human \\ Rights of the Azerbaijan National Academy of Sciences \\ УДК 347.233 \\ DOI 10.32782/EP.2021.2.20
}

The article notes that among the international legal acts devoted to the realization of property rights the Universal Declaration of Human Rights of 10 December 1948, the European Convention for the Protection of Human Rights and Fundamental Freedoms of 4 November 1950 and its Protocol No.1 are of particular importance.

Elements of the realization of property rights are reflected in general form in international legal acts. Depending on the specific circumstances, it is difficult to determine whether the requirements for the exercise of property rights are met. In this regard, legal certainty is contained in the precedents of the European Court of Human Rights.

Keywords: Constitution, law, article, property, concept.

When talking about the role of international legal acts in the realization of property rights, first of all it is necessary to look at the concept of realization of the right and to explain the content of the forms of realization of the right. Because one of the forms of thinking that man uses in the process of perception is a concept. It is through concepts that a person discovers the inner unity and content of events and processes in the world, acquires new knowledge about reality. The scientific literature defines a concept as follows: "A concept is a form of thinking that reflects the most important and distinctive features of objects" [1, p.20]. In other words, a concept is a form of thinking that reflects the essential features of objects and events, that is, all the changes that take place in nature.

According to A.D.Getmanova, "concept is a form of thinking that reflects the important and different features of any object or objects of the same category" [2, p.26].

A concept is the result of the generalization of some class of objects, such as a form of thought or a derivative of thought, and the separation of ideas of that class itself on a certain set of things common to those class objects and on a set of different features for them.

Each concept is an act of theoretical perception, that is, it shows how the reflected event realizes itself in reality, how its essence is revealed, how it is distinguished from other objects.

S.S.Suleymanli, referring to the German lawyer Hermann Kantorowich, states that "concepts (terms) have a very decisive role in any field of science. Because the first cornerstones in any field of science are inevitably built through concepts. From this point of view, the definition of concepts is always important. Defining a concept, as in naming, is not only a means of distinguishing one thing from another by defining it, but also a more detailed explanation of that thing. In other words, the definition of a concept should not only provide information about the scope of a word, but also the necessary knowledge and information about the issue and meaning expressed by the defined concept" [3, p. 27].

Scientific concepts are the whole ideas about the regularity and necessity in the events and processes of the surrounding world. Therefore, when assessing the role of legal concepts, including the concept of "realization of the right", the question of how accurately, adequately and objectively they reflect the perception of reality comes to the fore. 
"Speaking about the features of an object, we mean its similarities or differences with other objects" [4, p. 31].

Every concept that has emerged as a result of the generalization of human experience has a content and scope. The content of a concept is a set of important features of the object it expresses. For example, the content of the concept of "property" includes its important features. Content is very important for understanding. There is no contentless concept.

As mentioned above, along with the content, there is a scope for each concept. Scope is the sum of the objects reflected in that concept. For example, the concept of the definition of "property" includes all types of property.

According to T.Y.Falkina "the implementation of law is a complex multifaceted phenomenon, which is considered as the result (the final stage of legal regulation) and as a process of transformation of legal prescriptions into practice through the implementation of subjective rights and legal obligations" [5, p. 7].

According to R.R.Palecha "the implementation of the law ensures the embodiment of legal prescriptions in the behavior of various subjects of law" [6, p. 8].

V.N.Khrapanyuk gives a similar definition to the realization of the law that "the realization of legal norms is the embodiment of their requirements in people's behavior" [7, p. 182].

According to the scientific literature, there are 4 (four) forms of implementation of legal norms:

1) exercise of rights (use of rights);

2) performance of duties;

3) comply with duties;

4) application of legal norms.

The exercise of rights is reflected in the realization of the opportunities provided by legal norms to the participants of public relations. For example, the implementation of norms reflecting property rights.

The performance of duties is expressed in the mandatory performance of active actions required by law.

Observance of duties is expressed in refraining from committing acts prohibited by law. Citizens by not acting in a way that is prohibited by law, are fulfilling the requirements of these norms.
Application of legal norms - "this is the activity of the authorities on the implementation of legal norms by the competent state bodies in relation to specific life events and certain individuals" [7, p. 183].

We consider it necessary to note that the right of ownership represents a very important sphere for international legal regulation, as it is a fundamental institution of private law. However, the process of international legal unification of the institution of property law is faced with great difficulties of an objective nature due to significant differences between legal systems on this issue. It is sometimes very difficult, sometimes unfeasible to formulate a single rule of international character concerning property rights.

As V.V.Starzhenetsky correctly points out, "perhaps this explains the small proportion of the norms on property rights in private international law, which directly regulate proprietary relations. It should be recognized that the conflict method of legal regulation has always been considered one of the main method in this area. Only certain fragments of the statics of property turnover (as a rule, associated with foreign investments) were regulated by the direct method.

Almost all researchers involved in comparative law in the field of property law come to the unanimous opinion that property law is the most complex institution of private law in terms of many qualitative differences in its legal regulation. At the same time, differences are manifested both between the Anglo-Saxon and Continental legal families, and within legal systems belonging to the same legal family" [8, p. 42].

We would like to note that among of the international legal acts dedicated to the realization of property rights the "Universal Declaration of Human Rights" of December 10, 1948, consisting of 30 articles [9] and Protocol No. 1 of 20 March 1952 of the European Convention for the Protection of Human Rights and Fundamental Freedoms of 4 November 1950, consisting of 59 articles (The Republic of Azerbaijan has ratified this Convention and its Protocols No. 1, 4, 6, and 7 in accordance with the Resolution of the Milli Majlis of December 25, 2001) are of particular importance [10].

Pursuant to Article 17 of the "Universal Declaration of Human Rights" of December 10, 1948, "Everyone has the right to own property 


\section{Цивільне, підприсмницьке, господарське та трудове право}

alone as well as in association with others. No one shall be arbitrarily deprived of his property".

In accordance with Article 1 of Protocol No. 1 of 20 March 1952 (this Protocol consists of 6 articles) entitled „Protection of Property”, „Every natural or legal person is entitled to the peaceful enjoyment of his possessions. No one shall be deprived of his possessions except in the public interest and subject to the conditions provided for by law and by the general principles of international law. The preceding provisions shall not, however, in any way impair the right of a State to enforce such laws as it deems necessary to control the use of property in accordance with the general interest or to secure the payment of taxes or other contributions or penalties".

As can be seen, the elements of the realization of property rights are reflected in general form in international legal acts. Depending on the specific circumstances, it is difficult to determine whether the requirements for the implementation of property rights are met. In this regard, legal certainty is contained in the precedents of the European Court of Human Rights. The Convention and its precedents set general standards for the exercise of property rights.

The notions of "property" or "possessions" are widely interpreted in the precedents of the European Court of Human Rights in connection with the application of Article 1 of Protocol No. 1 of the European Convention on the "Protection of Human Rights and Fundamental Freedoms". According to the precedents of the European Court, "property right" includes:

- movable and immovable things;

- tangible and intangible interests (eg shares, patents);

- court decision on the claim

- right to pension;

- the right to receive rent;

- interests related to the implementation of business activities;

- the right to engage in this or that profession;

- hoping that certain conditions will be applied to the situation awaiting legal solution, etc.

According to the precedents of the European Court, "property rights include the following 3 (three) possibilities:

1) unimpeded use of his property by the owner;
2) inadmissibility of deprivation of property;

3) control over the use of property" [11].

The European Court of Human Rights stated in its judgment of 7 May 2002 in the Burdov v. Russia case: "A claim may be construed as "property" in the sense of Article 1 of Protocol No. 1 to the Convention, provided that the legal exercise of this requirement is sufficiently determined" [12].

The European Court of Human Rights, in its judgment in the case Öneryildiz v. Turkey on 30 November 2004, stated that the term "property" in Article 1 of Protocol No. 1 has an independent meaning not limited to property in respect of physical goods and does not depend on the formal classification in domestic law: the question is to determine whether the case as a whole is presented to the applicant on the basis of the material interests protected under that article. Accordingly, for the purposes of this provision, in addition to physical goods, some other rights and interests that constitute property may also be assessed as 'property rights' and as follows "property". The notion of "property" is not limited to "existing property" and may include the applicant's interests, including the requirement that he or she have at least reasonable and "legal expectations" for the effective exercise of the right to property [13].

In its judgment of 28 September 2005 in the Broniowski v. Poland case, the European Court of Human Rights stated that the definition of "property" in the first part of Article 1 of Protocol No. 1 had an independent meaning and did not depend on a formal definition in domestic law. Like tangible things, certain rights and interests that constitute property can be considered "property rights" and thus can be considered "property" for the purposes of this article [14].

The precedents distinguish between de jure and de facto alienation of property. Papamixalopoulos and others set an important precedent in the case against Greece (June 24, 1993) in this regard. The essence of this case was that the applicants owned a state-registered plot of land. However, the land was actually and indefinitely given to the military unit, and buildings for military units were built in the area. The violation lasted for many years, for indefinite time. The European Court of Human rights ruled that 
"formal alienation of property is not a condition for deprivation of property" [15].

The nationality of a person (natural or legal) does not matter when protecting property rights in the European Court of Human Rights. The right to property, being a human right, has the property of universality, which implies an equal approach to persons of different nationalities on the territory of one state. Therefore, protection in the European Court of Human Rights can also be obtained by foreign persons whose rights have been violated in a state party to the Convention for the Protection of Human Rights and Fundamental Freedoms.

We consider it necessary to state that international law and domestic (national) law are legal systems that operate independently, but are interconnected and interact with each other. The Constitution of the Republic of Azerbaijan take into consideration the issue of the normative rank of international treaties included in national legislation. The solution to this issue in Article 151 of the Basic Law is reflected as follows: "If there is a contradiction between normative legal acts included in the system of legislation of the Republic of Azerbaijan (excluding the Constitution of the Republic of Azerbaijan and acts adopted by referendum) and interstate treaties to which the Republic of Azerbaijan is a party, international treaties are applied" [16]. At first glance, it seems that in this article the Constitution enshrined the supremacy of international law. However, in fact, Article 151 plays the role of resolving possible contradictions between the provisions of an international treaty and normative legal acts of the Republic of Azerbaijan. As you can see, this article provides only for interstate treaties, to which the Republic of Azerbaijan is a party.

As for the legal force of intergovernmental agreements, it follows from subparagraph 6 of paragraph III of Article 130 of the Constitution that in the normative hierarchy they are below the Constitution and laws of the Republic of Azerbaijan.

In the scientific literature, it is noted that the category of property rights in international law has an autonomous meaning that does not coincide with that is accepted in national legal systems. International law considers property primarily through the categories of subjective rights, which implies the presence of a subject, an object and the powers of the subject. In international law, property rights are understood in a broader sense than in the national law of states. It includes the right to any property, property rights and other rights that have value, thus the value concept of property rights has been adopted. Its distinctive properties are: equality of subjects of private property, the extension of ownership of objects with signs of economic value and cash, regardless of their material or intangible nature, broad powers of the owner, the existence of an indefinite range of bearers of passive obligations, as well as the imposition of active duties on the state to ensure and protect property rights, moreover, in the system of international law, this should be enshrined in the framework of fundamental documents on human rights.

In modern conditions, the state is more and more actively intervening in private relations for the sake of ensuring public goals. International legal regulation sets the limits and conditions for the introduction of restrictive measures. The main requirement in this case is the observance of the principle of balance between public and private interests and the principle of proportionality. According to this principle, any interference with private rights is possible only in order to protect public interests and provided that the means chosen by the state to achieve it are proportional to the aim pursued.

The specificity of the legal mechanism for the protection of property rights is manifested in its two-level nature: at the international legal level, there are international norms and the protection mechanisms provided by them, such as diplomatic protection, protection in international courts, at the national legal level, domestic norms and remedies function [17, p. 7].

We would also like to note that Article 17 of the Charter of the European Union on Fundamental Rights, entitled "Property Rights", adopted on December 7, 2000 in Nice, France, provides for the protection of property rights. The mentioned article envisages that "Everyone has the right to own, use, dispose of and bequeath his or her lawfully acquired possessions. No one may be deprived of his or her possessions, except in the public interest and in the cases and under the conditions provided for by law, subject to fair compensation being paid in good time for their 


\section{Цивільне, підприсмницьке, господарське та трудове право}

loss. The use of property may be regulated by law in so far as is necessary for the general interest.

Intellectual property shall be protected".

\section{Bibliographic references}

1. Hacıyev Z.C. Məntiq: Dərs vəsaiti. Bakı: «Təhsil» NPM, 2011, $240 \mathrm{~s}$.

2. Гетманова А.Д. Аогика. - Москва: Новая школа, - 2000, 164 с.

3. Süleymanlı S.S. Mülki hüququn əsasları. Bakı: Hüquq Yayın Evi, 2019, 500 s.

4. Кириллов В.И., Старченко А.А. Аогика: Учебник. 6-е издание, переработанное и дополненное. Москва: Проспект, 2011, 240 с.

5. Фалькина Т.Ю. Формы реализации права и механизм их осуществления: Автореф. дисс. ... канд. юр. наук. Нижний Новгород, 2007, 26 с.

6. Палеха Р.Р. Природа правоприменения как особой формы реализации права: Дисс. ... канд. юр. наук. Елец, 2006, 171 с.

7. Xrapanyuk V.N. Dövlət və hüquq nəzəriyyəsi (ixtisarla) / Rus dilindən tərcümə edənlər Həmid Baratlı və İlham Đsədov. Bakı: Qanun, 2007, 248 s.

8. Старженецкий В.В. Соотношение международного (европейского) и российского правового регулирования института собственности: Дисс. канд. ... юр. наук. Москва, 2003, 171 c.

9. Universal Declaration of Human Rights. https://www.un.org/en/about-us/universal-declaration-of-human-rights

10. "Insan hüquqlarının və əsas azadlıqların müdafiəsi haqqinda" Konvensiyanın, onun 1, 4, 6, və 7 saylı Prorokollarının təsdiq edilməsi barədə" 25 dekabr 2001-ci il tarixli Azərbaycan Respublikasının Qanunu. http://www.e-qanun. az/framework/1405

11. Sporrong and Lönnroth $\mathrm{v}$ Sweden, Judgment, Merits, App no 7151/75 (A/52), App no 7152/75 (A/52), IHRL 36 (ECHR 1982), 23rd September 1982, European Court of Human Rights.

https://hudoc.echr.coe.int/eng\# $\{\% 22$ item id\%22:[\%22001-55434\%22]\}

12. European Court of Human Rights. Case of Burdov v. Russia (Application no. 59498/00), Judgment, Strasbourg, 7 May 2002, Final 04/09/2002.
13. European Court of Human Rights. Case of Öneryildiz v. Turkey (Application no. 48939/99), Judgment, Strasbourg, 30 November 2004.

https://hudoc.echr.coe.int/fre\# $\{\% 22$ item id\%22:[\%22001-67614\%22]\}

14. European Court of Human Rights. Case of Broniowski v. Poland (Application no. 31443/96), Judgment, Strasbourg, 28 September 2005.

https://hudoc.echr.coe.int/fre\# $\{\% 22$ item id\%22:[\%22001-70326\%22]\}

15. Case of Papamichalopoulos and others v. Greece (Application no. 14556/89) Judgment Strasbourg 24 June 1993. https://www.legal-tools. org/doc/05296f/pdf/

16. Конституция Азербайджанской Республики от 12 ноября 1995 года. https://online.zakon.kz/Document/?doc id $=30420395$

17. Мингазова И.В. Защита права собственности иностранных юридических и физических лиц в международном праве: Автореф. ... дисс. канд. юр. наук. Казань, 2006, $28 \mathrm{c}$.

Фараджова Гандаб Имран квизи - диссертант Института права и Прав Человека Наџиональной Академии Наук Азербайджана РОАЬ МЕЖДУНАРОДНЫХ

\section{ПРАВОВЫХ АКТОВ ПРИ РЕААИЗАЦИИ} ПРАВА СОБСТВЕННОСТИ

В статье отмечается, что в число международно-правовых актов, посвященных реализации прав собственности, входят Всеобщая декларация прав человека от 10 декабря 1948 г., Европейская конвенция о защите прав человека и основных свобод от 4 ноября 1950 г. и Протокол № 1 к ней.

Элементы реализации права собственности в общем виде отражены в международно-правовых актах. В зависимости от конкретных обстоятельств сложно определить, выполняются ли требования по осуществлению прав собственности. В этом отношении правовая определенность содержится в прецедентах Европейского Суда по Правам Человека.

Ключевые слова: Конституция, право, статья, имущество, понятие. 